\title{
Autosomal recessive diseases among the Athabaskans of the southwestern United States: anthropological, medical, and scientific aspects
}

\author{
Robert P. Erickson ${ }^{1}$ (D) \\ Received: 3 February 2021 / Revised: 31 March 2021 / Accepted: 5 April 2021 / Published online: 21 April 2021 \\ (C) Institute of Plant Genetics, Polish Academy of Sciences, Poznan 2021
}

\begin{abstract}
The peopling of the Americas by Native Americans occurred in 4 waves of which the last was Nadene language speakers of whom Athabaskans are the largest group. As the Europeans were entering the Southwestern states of the USA, Athabaskan hunting-gathering tribes were migrating South from Canada along the Rocky Mountains and undergoing potential bottlenecks reflected in autosomal recessive diseases shared by Apaches and Navajos. About 300 years ago, the Navajo developing a sedentary culture learned from Pueblo Indians while the Apache remained hunter-gathers. Although most of the tribe was rounded up and forced to relocate to Bosque Redondo, the adult breeding population was large enough to prevent a genetic bottleneck. However, some Navajo underwent further population bottlenecks while hiding from the brutal US Army action (under Kit Carson's guidance). This led to an increased frequency of other autosomal recessive diseases. Recent advances in population genetics, pathophysiology of the diseases, and social/ethical issues concerning their study are reviewed.
\end{abstract}

Keywords Athabaskan $\cdot$ Apache $\cdot$ Navajo $\cdot$ Population bottlenecks $\cdot$ Native Americans $\cdot$ Autosomal recessive diseases

\section{Introduction}

Two previous reviews at about a decade interval described the population history of Southwestern Athabaskans (Apache and Navajo) which resulted in genetic bottlenecks and the accumulation of recessive alleles for a particular spectrum of recessive genetic diseases (Erickson 1999, 2009). In the last decade, the results of DNA sequencing of ancient skeletal remains have advanced our knowledge of the movements of Amerinds and the origins of the Athabaskans ("Athapaskans" is preferred by linguists). The molecular and cellular biology of the diseases which were found with increased frequency among some of them has greatly advanced. Table 1 lists the diseases with increased frequency among the Athabaskans, including several which were previously discussed (Erickson 2009) but for which there is no new data. Navajo views of genetics may be showing a slow shift to acceptance of genetic

Communicated by: Michal Witt

Robert P. Erickson

erickson@peds.arizona.edu

1 Department of Pediatrics, University of Arizona, Tucson, AZ, USA studies and testing. This new knowledge is herein reviewed. A thoughtful review of all genetic research on the Navajo, framed in view of Navajo culture and values, is that of Begay et al. (2020).

\section{Athabaskan (Nadene) affinities updated}

In the previous review (Erickson 2009), it was concluded that "genetic and linguistic data suggest that the Nadene [a language family], of which the Athabaskans [speakers] are the largest group, are part of a later immigration into the Americas than the first Amerind immigrations." The data supporting this conclusion were both linguistic and from DNA analyses of $Y$ chromosomal and mitochondrial DNA. Further analyses of the these 2 sources of DNA further supported the relationship of Siberians and Amerinds with a divergence of about 13,000 years (Dulik et al. 2012) and the identification of "Beringia" with to-and-fro migration across the Bering Strait. However, while the linguistic data reviewed previously (Erickson 2009) strongly suggested affinities to Northern Siberian (Altaian) ethnic populations, the newer mitochondrial and Y chromosomal DNA analyses supported affinities 
Table 1 Autosomal recessive diseases with increased frequency in one or more Athabaskan populations with mutations when known and the population frequency from the genome (references in text)

\begin{tabular}{|c|c|c|c|c|c|}
\hline Tribal affiliation & Disease & Gene & Mutation & Designation & Frequency \\
\hline \multicolumn{6}{|c|}{ Navajo and Apache } \\
\hline & HOXA1 deficiency & HOXA1 & $76 \mathrm{C}>\mathrm{T}$ & Rs104894018 & 0.00002 \\
\hline & Poikiloderma with neutropenia & USB1 (C16ORF57) & Unknown & & \\
\hline & Severe combined immunodeficiency & ARTEMIS (DCLREIC) & Exon8 $\mathrm{C}>\mathrm{A}$ & Rs121908157 & 0.000004 \\
\hline \multicolumn{6}{|c|}{ Western Navajo nation } \\
\hline & MP17 deficiency & $M P 17$ & $149 \mathrm{G}>\mathrm{A}$ & Rs121909721 & 0.00001 \\
\hline & Microvillar inclusion disease & MYO5B & $1997 \mathrm{C}>\mathrm{T}$ & Rs121908106 & 0.00004 \\
\hline & Navajo variant OFDIX & Unknown & & & \\
\hline \multicolumn{6}{|c|}{ Eastern Navajo nation } \\
\hline & Xeroderma pigmentosum & Unknown & & & \\
\hline \multicolumn{6}{|c|}{ Navajo nation unspecified } \\
\hline & Metachromatic leukodystrophy & ARSA (arylsulfatase A) & Intron 4, nt $1, \mathrm{G}>\mathrm{A}$ & RCV000003222.3 & None reported \\
\hline & Oculocutaneous albinism II & $O C A 2$ & $122.5 \mathrm{~kb}$ deletion & RC000001010 & Unique \\
\hline & Methemoglobinemia & Unknown & & & \\
\hline & Retinitis pigmentosa & Unknown & & & \\
\hline
\end{tabular}

with linguistically different Southern Altaians (ibid.). The analyses of ancient genomes from Siberia also suggest that, although Native Americans share relationships with the "ancient Paleo-Siberians," and that they do not with the "NeoSiberians" which are the ancestors of many contemporary Siberian populations (Sikora et al. 2019). Their data was also consistent with a divergence of Ancient Beringians from Native Americans in Eastern Beringia rather than in Siberia with gene flow from Native Americans to Siberians about 3000 years before the present (ibid.). These somewhat conflicting data can be understood in terms of further movements, e.g., Southern Altaians to Northern Siberia, which seem especially abundant among hunter-gatherers. Recent advances in DNA sequencing of nuclear DNA in extant Native American groups and of DNA obtained from archeological "digs" support and further amplify these relationships. This sequencing of ancient DNA has profoundly changed our knowledge of the relationships of all human populations. The major technological advance allowing these studies was the discovery that the interior of teeth could provide DNA non-contaminated with bacteria or fungi. In regard to Native Americans, it was surprising to find that ancient Europeans are more closely related to Native Americans of the era than they are to East Asians (Patterson et al. 2012). This reflects a shared ancestry with an ancient North Eurasian population which Inuits do not share. Roughly $1 / 3$ of the Native American genome comes from the inferred ancient population which is also identified in the sequence of a 29,000-year-old sample from South Central Siberia (the Mal'ta sample; Raghavan et al. 2014).
The analyses of ancient DNA samples establish 4 , not the previously considered 3, waves of immigration to the Americas: (1) the first probably proceeded the opening of the ice-free corridor and is likely to have used the shores sometimes then present along the West side of the continental ice sheet, a strong probability as represented by the marine peopling of the $2000 \mathrm{~km}$ long Aleutian archipelago (Balter 2012). These are probably represented by preClovis (New Mexico, long considered the oldest Amerind site), archeological sites such as that of Monte Verdi (Dillehay et al. 2008). This earlier population may reflect the ancient population with Australasian affinities that Skoglund et al. (2015) identified as contributing to some isolated Brazilian populations. These authors called this the $Y$ lineage and its affinities are with New Guineans and the aborigines of Australia. This earlier migration had previously been supported by mitochondrial sequences (Fagundes et al. 2008). (2) The vast percentage of most Native American DNA sequence is shared and can be equated with the Clovis culture (Reich et al. 2012) concurring with the second migration when a corridor opened through the ice sheet. (3) However, the Nadene speakers, mostly Athabaskan speakers, differ by having $10 \%$ of their DNA markers related to a newer Asian lineage with the rest shared with the major Amerind lineage (ibid.) and represent the third migration. (4) Eskimo-Aleuts have an even higher, $40 \%$ contribution of markers from this Asian lineage and represent the fourth migration. These last two migrations have been named the Paleo-Eskimos, represented by Nadene speakers who arrived about 5000 years ago, and 
Neo-Eskimos (Flegontov et al. 2019). The nuclear DNA sequences also affirm the Beringia hypothesis with the Chukchi of Northeastern Siberia sharing $40 \%$ of their DNA markers with Amerinds (Reich et al. 2012). An interesting variant in carnitine palmitoyltransferase thought to be important for the metabolism of long-chain fatty acids has had a genetic "sweep" in Northeastern Siberians and Canadian and Greenland Inuits but does not seem to have occurred in Athabaskans (Clemente et al. 2014). The pathogenic variant decreases fatty acid oxidation and ketogenesis which may be adaptive to the high-fat diet and elevates HDL and reduces adiposity (ibid.).

The older linguistic data also had supported the third wave when Nadene was identified by Sapir (1915) as a distinct linguistic group from other Amerind language families of which there are 25 (one can get an idea of how much this diversity represents since Indo-European is a language family including English to Sanskrit). The linguistic data had also suggested to Hirsch (1954) that the Nadene had arrived about 3000 years ago and might have entered after the Eskimo-Aleut and separated them into Northern and Southern populations. The relationship of the Navajo language to that of Ket in Northern Siberia previously discussed has been strengthened by newer statistical tests (Diamond 2011). Analyses of material culture also support the recent arrival of Athabaskans and provide a probable mechanism for their ability to dominate previously arrived Native Americans in the areas where they have displaced them. As argued by Wilson (2011), following a thorough survey of bows in museum and other collections, they introduced the sinew-backed bow, a great advance in archery, allowing a much more powerful pull. The sinew-backing allowed a shorter and sometimes recurved bow. It was used by the Mongol invaders of Europe to great advantage and its presence among the Athabaskans may reflect cultural continuity with this more recent bow-making tradition. Wilson also points out similarities in the sand paintings of Navajos and Tibetans: "the nine-day sand painting rites of Tibetans and Athabascan Navajo share colours, symbols, rules, and names, pointing to the adoption of both systems within the past millennium" (Wilson 2005). They, like Navajo sand paintings, are deliberately destroyed when the ritual is over.

\section{Apache and Navajo population-enriched autosomal recessive diseases}

There have been many advances in our understanding of the pathophysiology of the 3 diseases previously described as being present at increased frequency in both the Navajo and the Apache: HOXA1 deficiency, Poikiloderma with neutropenia, and severe combined immunodeficiency (SCID). As previously discussed, the recessive alleles for these must have shared a bottleneck before the Apache and Navajo separated, the Navajo to develop a Pueblo Indian pastoral lifestyle, and the Apaches to remain hunter-gatherers. Thus, the presumed bottleneck had occurred as small bands migrated along the plateaus from which the Rockies rise to the American Southwest although analyses of kinship structures and terms suggest a high plains route with other proto-Apacheans (Opler 1936).

The gene for the previously discussed methemoglobinemia shared by Dine (the name the Navajo use for themselves) of Alaska, the Southwest Athabaskans, and possibly some Siberians, has been identified as CYB5R3 and the causative mutation found with a disease frequency of 1/1250 among Yakuts (Galeeva et al. 2013). It would be interesting to know whether this pathogenic variant is present among the presentday Southwestern Athabaskans.

\section{HOXA1 deficiency (previously Athabaskan brainstem dysgenesis)}

This disorder was the first recessive $H O X$ gene-determined disease. Initially thought of as a genetic form of "Moebius Syndrome," the patients shared features of lateral gaze palsy (Duane Retraction syndrome), central hypoventilation, sensorineural deafness, facial palsy, and, in the Athabaskans, developmental delay (Holve et al. 2003). An astute graduate student, Max Tischfield in Elizabeth Engel's laboratory at Harvard, recognized the great similarity to an autosomal disorder described, but not yet published, in consanguineous Saudi Arabian patients and which has since been named "Bosley-Salih-Alorainy Syndrome" (Bosley et al. 2007). These patients had spent their lives at a lower altitude than the Athabaskan patients, possibly explaining their much milder developmental delay - presumably by the time the higher $\mathrm{CO} 2$ level required to stimulate breathing occurred, not as much neuronal death due to hypoxia had occurred. Of the 4 patients with cerebral atrophy on MRI, from 29 in the combined Arabian and Athabaskan group, only one was Saudi Arabian and had hypoxia during cardiac surgery (Bosley et al. 2008). The high altitude hypoxic nerve damage might mirror the transient white matter abnormalities reported in some Charcot-Marie-Tooth patients after visits to high altitudes (Paulson et al. 2002). An Athabaskan-specific mutation, differing from the Arabian one, was soon found (Tischfield et al. 2005; Table 1 and Fig. 1).

The fuller clinical description of 29 HOXA1 deficient patients found that Duane Retraction syndrome was the most consistent feature in 27/29 patients (Bosley et al. 2008). Hearing loss was present in 26 of the 29 cases. Previously more commented on in the Athabaskan patients, congenital heart disease of conotruncal or septal defects, including double outlet right ventricle, anomalous pulmonary venous return, ventricular septal defects and even tetralogy of Fallot were 
Fig. 1 Navajo sandpainting, photogravure by Edward S. Curtis, 1907, Library of Congress

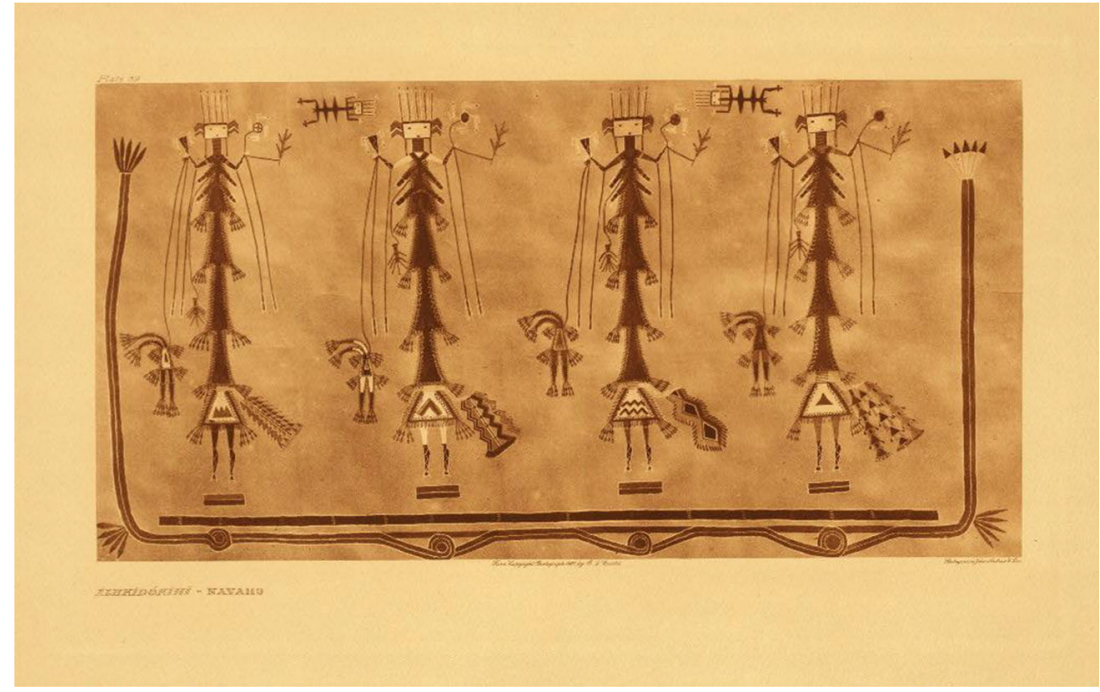

delimited (Bosley et al. 2008). Heart defects had been found in only one laboratory's Hoxal knockout (Nadja and Capecchi 2012). This laboratory's knockout of Hoxal, surprisingly, since not reported in previous studies of Hoxal knockouts, showed neonatal death with $74 \%$ of the embryos having interrupted aortic arch, aberrant subclavian artery, or Tetralogy of Fallot.

Further understanding of the developmental defects in brain neuronal circuits was also described in another Hoxal knockout in which ectopic neuronal groups in the hindbrain established a supernumerary neuronal circuit from mutant rhombomere 3-4 that escaped apoptosis (Del Toro et al. 2001). This network altered the rhythm-generating circuitry which controls respiration after birth. HOXA1's role in the developing rhomobomere may be mediated by retinoic acid-embryonic stem cells deficient in Hoxa1, unlike the controls, could not develop into neurons after treatment with all-trans-retinoic acid (Martinez-Caballos and Gudas 2008). Hoxbl can be exchanged for Hoxal by knock-out/knock-in technology, using the latter's controlling elements (and vice versa), resulting in normal mice which demonstrate the importance of the regulatory elements for the different patterns of expression (Tvrdik and Capecchi 2006). A fuller treatment of the detailed pathophysiology of the disorder is available in Tischfield et al. (2016).

\section{Poikiloderma with neutropenia (also known as poikiloderma with neutropenia, Clericuzio-type)}

As previously discussed (Erickson 2009), although once considered only a Navajo disease, one clear-cut case in an Apache suggested otherwise. In the interval since the previous review, the DNA sequence in which causative mutations occur has been identified in Europeans. Pathogenic variants in an open-reading frame determining a sequence of previously unknown function, C16orf57, were found (Volpi et al. 2010). Protein network analyses (Colland et al. 2004; Rual et al. 2005) had indicated that the predicted protein would interact with SMAD4 which, through other intermediary proteins, would interact with RECQL4, the gene for which is mutated in Rothmund-Thompson syndrome. Because of the overlap in phenotype, RECQL4 had been sequenced in 3 Poikiloderma with Neutropenia Navajo patients with negative results (Wang et al. 2003). This open reading frame gene has since been found to code for a U6 small nuclear RNA biogenesis phosphodiesterase, USB1(Mroczek et al. 2012). Concolino et al. (2010), in their clinical description of 3 Italian patients in whom mutations had been found, added facial dysmorphism to the poikiloderma, neutropenia, dystrophic nails, and short stature previously described. The facies affected the midface, including the nose, and eyebrow hypoplasia with wide-spaced eyes, depressed nasal bridge, and frontal bossing. A 10-year followup of the 3 patients (Concolino et al. 2019) showed that the frequency of sinopulmonary infections had decreased although there was persistent neutropenia and there was no evidence of skin cancer or myelodysplasia.

\section{Severe combined immunodeficiency}

As previously described (Erickson 2009), the identification of a specific pathogenic variant in ARTEMIS (DCLRE1C, Li et al. 2002a) allowed the establishment of genetic screening by assaying for $\mathrm{T}$ cell receptor excision circles ( $\mathrm{Li}$ et al. 2002b) and early bone marrow transplantation. As also pointed out previously, instead of a mutation in ARTEMIS, a different mutation, a pathogenic variant in $R A G-1$, was found to be the cause of severe combined 
immunodeficiency (SCID) among Athabaskans of Canadian Northwest Territories (Xiao et al. 2009), supporting the notion that a further bottleneck occurred during the migration of the Apache and Navajo to the American Southwest. The ARTEMIS mutation led to radiation sensitivity (Nicolas et al. 1998) and increased risk of lymphoma (Moshous et al. 2003) although some pathogenic variants in ARTEMIS only resulted in antibody deficiency (Volk et al. 2015). Thus, it was a more severe condition than that caused by the $R A G-1$ mutation.

\section{Navajo population-enriched diseases}

The Navajo separated from other Apachean speakers (the languages are closely related, as an Apache acquaintance said, "we can understand the Navajo if they hurry up and speak a little faster") at the beginning of recorded history in the Southwest. The first archeological record of a Navajo Hogan was at the Governador Canyon in north-central New Mexico, dated by tree rings between 1480 and 1560 (Hall Jr. 1944). They may have arrived much earlier and been responsible for the movement of the Anasazi (pre-Pueblans) from dwelling on top of the mesas to cliffs on the sides of the mesas in the twelfth century.

Governador Canyon is near the Rio Grande pueblos and the archeological findings could indicate the start of a 300 year-long period of interaction between Navajos and Pueblo cultures during which they became agriculturists and picked up such traits as matrilineal clans (Spencer 1947, cited in Vogt 1961). Such clan organization reflected a more settled, agricultural life (Kaut 1956). The Navajos continued the raiding style of other Apaches, both against Pueblo Indians and the Spanish, capturing thousands of sheep and horses.

While men would be killed, women and children were frequently kidnapped and incorporated into the tribe, leading to some genetic intermingling with Pueblans. The latter had their own bottlenecks, such as the Zuni who have a high incidence of cystic fibrosis (Grebe et al. 1992).

These raids continued, against Americans as well (when they displaced the Spanish), and this led to early military actions against them. These ceased during the Civil War but restarted after it, eventually leading to devastating US Army action against the Navajo, culminating in Kit Carson leading troops under General Carleton in 1863. "The program that ensued was guided by probably the severest Indian policy ever carried out in the Southwest" (Vogt 1961) and led to their incarceration at Bosque Redondo.

As suggested by Holve et al. (2001) and previously mentioned (Erickson 2009), the bottlenecks that increased the carrier frequency of some mutations in the Navajo were probably among small groups which managed not to get captured. The probable breeding adult population of about 2000 at Bosque Redondo was large enough not to result in a bottleneck. The current locations of patients affected with some of these disorders separate into the Western part of the Reservation (Holve et al. 2001) and the Eastern part of the Reservation.

\section{Western reservation Navajo population-enriched autosomal recessive diseases}

MPV17 deficiency (also known as Navajo neurohepatopathy) The evolving description of this disease was previously covered (Erickson 2009). As well described by Holve et al. (1999), about $25 \%$ of the case present in infancy with the predominant liver disease while older children can present either with liver disease or with the neurological disease of severe anesthesia leading to acral mutilation, corneal ulceration, and painless fractures associated with severe weakness, sexual infantilism, depressed weight, and increased systemic infections. Although originally not described (the doctors were working through interpreters and could/did not ascertain verbal facility), most patients were mild to moderately developmentally delayed. Findings of decreased liver mitochondria (Vu et al. 2001) were consistent with the homozygosity mapping of the causative gene to, and finding a Navajo-specific pathogenic variant in, MPV17, previously implicated in an infantile hepatocerebral form of mitochondrial depletion syndrome (Karadimas et al. 2006). The mouse knockout showed the greatest deficiency of mitochondria in the liver and skeletal muscle but much less in the brain and kidney (Viscomi et al. 2009). Nonetheless, the mice developed severe glomerulosclerosis with massive proteinuria late in life. In humans, the relative amounts of mitochondrial depletion are not known but the most affected organs reflect the tissues with the highest metabolic needs.

Seventy-five published cases of MPV17 deficiency were summarized along with 25 new cases by El-Hattab et al. (2018). Early-onset, especially of the hepatic abnormalities of cholestasis and steatosis, occurred in most patients and frequently led to liver failure. Indeed, frank liver failure was the frequent cause of death in the first decade of life (75\%). Thus, early diagnosis and consideration for liver transplantation are needed. Lactic acidemia sometimes was present.

The neurologic deterioration continued and feeding difficulties, seizures, and microcephaly with leukodystrophy were associated with peripheral neuropathy. Although one Italian family had the identical mutation to that of the Navajos, they occurred on completely different haplotypes, indicating independent origins (Spinazzola et al. 2008).

Microvillous inclusion disease (also known as congenital familial protracted diarrhea with enterocyte brush-border abnormalities classified by OMIM as diarrhea 2 , with microvillous atrophy) The previous review described the delineation of this diarrheal disorder, which is so severe that the liquid 
feces are frequently misinterpreted as urine, and the finding of an increased frequency among the Navajo (Erickson 2009). The distinctive EM pathology of shortening or absence of apical microvilli with pathognomonic microvillus inclusions in mature enterocytes led to the disease name. The identification of the mutated gene as MYO5B (Muller et al. 2008) and the identification of the Navajo-specific pathogenic variant (Erickson et al. 2008) were also detailed. In the intervening years, there have been major increases in the understanding of the cellular mechanisms underlying the pathophysiology but basically no advance in treatment. Studies in cultured cells showed that the knockdown of MYO5B did not cause microvillous inclusions but replacement of the normal gene with the mutant gene did cause them, suggesting an altered function with this mutation (Knowles et al. 2014). It was found that the loss of interaction between RAB11A and MYO5B induced the microvillous inclusions (ibid.). As studied in intestinal biopsies from the patients, excess chloride secretion mediated by the CFTR was largely responsible for the diarrhea (Engevik et al. 2018). For the moment, only bowel transplantation provides hope for survival but the development of a pig model via CRISPR allows hope for advances in the future (Goldenring 2020).

Navajo-variant oral-facial-digital syndrome This variant differs from other reported cases of Oral-facial-digital (OFD) IX syndrome by its severe microcephaly. It had been found in two pairs of Navajo siblings and was detailed in the 2009 review (Erickson 2009). Severe singleton cases of OFD IX, with much greater eye abnormalities and other birth defects and shortened survival, were found to have pathogenic variants genes for ciliary proteins, TBC1D32 and SCLTl(Adly et al. 2014). The finding of a cilia-related mutation conforms to the findings in OFDI in which the X-linked gene product, OFDI, is expressed in nodal cilia where it controls the length and structure of centrioles (Singla et al. 2010). Among 56 patients with OFD of various subgroups and who were negative for pathogenic variants in OFD1, C2D3 mutations were associated with severe microcephaly in several unclassified patients (Bruell et al. 2017). OFD1 was sequenced and searched for re-arrangements in 2 Navajo patients, with unaffected siblings for controls, with negative results (Dr. Christel Thauvin-Robinet, Centre de Genetique, Dijon, France; unpublished results). The whole exome sequencing of 2 patients and sib controls by Dr. Fowzan S Alkuraya, Department of Genetics, King Faisal Specialist Hospital (unpublished results) also did not disclose a mutational cause of the Navajo disorder. It remains likely to be caused by pathogenic variants in a gene(s) involved in cilia function or structure as argued by Toriello (2009). KIF 11, mutations in which cause MCLMR (microcephaly with or without chorioretinopathy, lymphedema, or mental retardation) with its overlapping phenotype, is a good candidate gene (Jones et al. 2014). It, like many ciliary genes, codes a microtubule motor that functions during mitosis in microtubule crosslinking and antiparallel microtubule sliding. Thus, the Navajo variant could be caused by mutations in one of many genes.

\section{Eastern reservation Navajo population-enriched autosomal recessive diseases}

Xeroderma pigmentosum The one disorder which only occurred on the Eastern side of the reservation was Xeroderma Pigmentosa which was described in 3 sibling pairs as reported (Erickson 2009). There still seems to be no characterization of the classification (A, B, C...), perhaps due to the lack of cases (see below). One case was the subject of a documentary film: "Sun Kissed" (PBS, S25 Ep11 | 5 m 18 s | Aired: 10/16/2012).

\section{Navajo reservation, a locale not described}

Retinitis pigmentosa Although only described in one report, the finding of 43 cases of autosomal recessive retinitis pigmentosa among the Navajo strongly suggests a founder effect as with the other entities reviewed (Heckenlively et al. 1981).

There seems to be no new information on methemoglobinemia (Balsamo et al. 1964), metachromatic leukodystrophy (Paster-Soler et al. 1994), or oculocutaneous albinism 2 (Yi et al. 2003), previously discussed in Erickson (2009) which are also included in Table 1.

\section{Is the frequency of these diseases changing?}

Of the Athabaskan diseases described, the larger number of cases has been among the Navajo. Despite the many hardships that their environment provides, they now number about 300,000 . Arthur and Diamond (2011) have argued that this great population success compared to other Native American tribes is due to isolation, decreasing the spread of disease (although not for COVID-19), and the right kind of natural resources - not gold, which would bring invasion by the dominant population of European descent, but coal, uranium, and natural gas. Since there is an abundance of coal elsewhere in the USA, exploiting it on the reservation was not a high priority for non-Natives. Nonetheless, it has become important for many Navajos, both who work in mines and who perform surface mining for personal use. As the Navajo poet, Jake Skeets has said "This is a retelling of the creation story where Navajo people journeyed through four worlds and God declared, 'Let there be coal'" (Skeets 2019). A highly adaptive culture, as reflected in a lifestyle borrowed from Pueblo 
Indians, is also very important. The increase in population with much greater movement around, and off, the reservation, which has occurred with modernization, would certainly decrease the likelihood of matings with related individuals.

In the last decade, the number of cases of these autosomal recessive diseases has fluctuated at low levels but not with a clear decrease. Only a careful review of the records at hospitals servicing Southwestern Athabaskans could quantitatively establish the fact.

\section{Future developments}

In the past, several authors have proposed important points for presenting general medicine in a culturally sensitive way to Navajos. This is especially required because of the great difficulties in translating Indo-Aryan languages, which are noun adjectives languages, into Navajo which is a verb language. For an instance of the low importance of verbs in English, the children's cartoon series "The Smurfs" can get by with only 1 verb, "to Smurf," for everything Smurfs do - subject and object, with a little help from the drawings, convey the action. The verb is central in Navajo and Apache languages. For instance, "throwing" can have many forms depending on what is thrown. The difficulties in translating are illustrated in the successful use of their language by the Navajo "code-talkers" in WWII.

Negative information needs to be provided in more sensitive ways than it is frequently presented to individuals of European descent (Carrese and Rhodes 2000). It is also important to consider that language probably sets limits on modes of thinking - the Sapir-Whorf hypothesis. Thus, patience is especially needed for genetic counseling with its frequently foreign notions. As Dr. Brian Volck, who has spent many years working in Tuba City on the Western Reservation, observes: "Traditional Navajo choose words carefully, value reticence, sing often, and rarely shout" (Volck 2016). The Indian Health Service (a branch of U.S.P.H.S.) has shown sensitivity to Navajo cultural needs by building special rooms for medicine men, "singers," to perform healing ceremonies in their newer hospitals.

European's culture also has different ethical values than that of the Navajo (Carrese and Rhodes 1995). These differences have been discussed (Bankoff and Perry 2016) and specific guidelines of performing research on ancient DNA provided (Wagner et al. 2020).

Recently, with Navajo scientists studying the ethics of genetic studies (Garrison et al. 2020), it is possible that a Navajo IRB more receptive to clinical genetic studies. The Navajo IRB, although previously denying any DNA testing on the reservation, allowed the screening test for SCID even though it involved measuring a component of DNA (excision circles). As many tribes, the Navajo are very sensitive to the possible misuse of genetic samples for studies of population genetics (discussed in Erickson 2009). Perhaps with more input from
Navajos like Nanabaa' Garrison, who has extensively studied the ethics of the interactions of scientists with Native Americans (Garrison et al. 2020), a less restrictive approach than the complete ban on genetic research will occur.

\section{Declarations}

Competing interests The author declares no competing interests.

\section{References}

Adly N, Alhashem A, Ammari A, Alkuraya FS (2014) Ciliary genes TBC1D32/C6orf170 and SCLT1 are mutated in patients with OFD type IX. Hum Mutat 35:36-40

Arthur R, Diamond J (2011) Understanding tribal fates. Science 334: 911-912

Balsamo P, Hardy WR, Scott EM (1964) Hereditary methemoglobinemia due to diaphorase deficiency in Navajo Indians. J Pediatr 65:928931

Balter M (2012) The peopling of the Aleutians. Science 335:158-161

Bankoff RJ, Perry GH (2016) Hunter-gatherer genomics: evolutionary insights and ethical considerations. Curr Opin Genet Dev 41:1-7

Begay RL, Garrison NA, Sage F, Bauer F, Knoki-Wilson U, Begay DH, Becenti-Pigman B, Claw KG (2020) Weaving the strands of life (Iiná Bitt'ool): history of genetic research involving Navajo people. Hum Biol 91:189-208

Bosley TM, Salih MA, Alorainy IA, Oystreck DT, Newster M, AbuAmero KK, Tischfiedl MA, Engle EC (2007) Clinical characterization of the HOXA1 syndrome BSAS variant. Neurol. 69:1245-1253

Bosley TM, Alorainy IA, Salih MA, Aldhalaan HM, Abu-Amero KK, Oystreck DT, Tischfield MA, Engle EC, Erickson RP (2008) The clinical spectrum of homozygous HOXA1 mutations. Am J Med Genet 146A:1235-1240

Bruell A-L, Franco B, Duffourd Y, Thevenon J, Jego L et al (2017) Fifteen years of research on oral-facial-digital syndromes: from 1 to 16 causal genes. J Med Genet 54:371-380

Carrese JA, Rhodes LA (1995) Western bioethics on the Navajo reservation: benefit or harm? J Am Med Assoc 274:12-189

Carrese JA, Rhodes LA (2000) Bridging cultural differences in medical practice: the case of discussing negative information with Navajo patients. J Gen Intern Med 15:92-96

Clemente FJ, Cardona A, Inchley CE, Peter BM, Jacobs G et al (2014) A selective sweep on a deleterious mutation in CPT1A in artic populations. Am J Hum Genet 95:584-589

Colland F, Jacq X, Trouplin V, Mougin C, Groizeleay C, Hamburger A, Meil A, Wojcik J, Legrain P, Gauthier JM (2004) Functional proteomics mapping of a human signaling pathway. Genome Res 14: 13244-11332

Concolino D, Roversi G, Muzzi GL, Sestito S, Colombo EA, Volpi L, Larizza L, Strisciuglio P (2010) Clericuzio-type poikiloderma with neutropenia syndrome in three sibs with mutations in the C16orf57 gene: delineation of the phenotype. Am J Med Genet 152A:2588 2594

Concolino D, Sestito S, Falvo F, Romano G, Ceravolo M, Anastasio E, Pensabene L, Colombo EA, Larizza L (2019) Assessment of intrafamilial clinical variability of poikiloderma with neutropenia by a 10-year follow-up of three affected siblings. Eur J Med Genet 62:73-76

Del Toro ED, Borday V, Davenne M, Neun R, Rijli FM, Chanpagnat J (2001) Generation of a novel functional neuronal circuit in Hoxal mutant mice. J Neurosci 21:5637-5642 
Diamond J (2011) Deep relationships between languages. Nature 476: 291-292

Dillehay TD, Ramirez C, Pino M, Collins MB, Rossen J, Pino-Navarro JD (2008) Monte Verde: seaweed, food, medicine and the peopling of South America. Science 320:784-786

Dulik MC, Zhadanov SI, Osiova LP, Askapuli A, Gau L, Gokcumen O, Rubinstein S, Schurr TG (2012) DNA and Y chromosomal variation provides evidence for a recent common ancestry between Native Americans and Indigenous Altaians. Am J Hum Genet 90:229-246

El-Hattab AW, Wang J, Dai H, Almannai M, Staufner C, Alfadhel M, Gambello MJ, Prasun P, Raza S, Lyons HJ, Afqi M, Saleh MAM et al (2018) MPV17-related mitochondrial DNA maintenance defect: new cases and review of clinical, biochemical, and molecular aspects. Hum Mutat 39:461-440

Engevik AC, Kaji I, Engevik MA, Meyer AR, Weis VG et al (2018) Loss of MYO5B leads to reductions in $\mathrm{Na}^{+}$absorption with maintenance of CFTR-dependent $\mathrm{Cl}^{-}$secretion in enterocytes. Gastroentero. 155: 1883-1997

Erickson RP (1999) Southwestern Athabaskan (Navajo and apache) genetic diseases. Genet Med 1:151-157

Erickson RP (2009) Autosomal recessive diseases among the Athabaskans of the Southwestern United States: recent advances and implications for the future. Am J Med Genet 149A:2602-2611

Erickson RP, Larson-Thomé K, Valenzuela RK, Whitaker SE, Shub MD (2008) Navajo microvillous inclusion disease is due to a mutation in MYO5B. Am J Med Genet A 146A:3117-3119

Fagundes NJR, Kanitz R, Eckert R, Valls ACS, Bogo M et al (2008) Mitochondrial population genomics supports a single pre-Clovis origin with a coastal route for the peopling of the Americas. Am J Hum Genet 82:583-592

Flegontov P, Altinisik NE, Changmai P, Rohland N, Maallick W et al (2019) Palaeo-Eskimo genetic ancestry and the peopling of Chukotka and North America. Nature 570:236-240

Galeeva NM, Voevoda MI, Spiridonova MG, Stepanov VA, Polyakov AV (2013) Population frequency and age of c.806 C $>$ T mutation in CYB5R3 gene as cause of recessive congenital methemoglobinemia in Yakkutia. Hum Genet 49:457-463

Garrison NA, Carroll S, Hudson M (2020) Entwined processes: rescripting consent and strengthening governance in genomics research with indigenous communities. J Law Med Ethics 48:418-410

Goldenring J (2020) Editing myosin VB gene to create porcine model of microvillus inclusion disease, with microvillus-lined inclusions and alterations in sodium transporters. Gastroenter. 158:2236-2249

Grebe TA, Doane WW, Richter SF, Clericuzio C, Norman RA et al (1992) Mutation analysis of the cystic fibrosis transmembrane regulator gene in Native American populations of the Southwest. Am J Hum Genet 51:736-740

Hall ET Jr (1944) Recent clues to Athabaskan prehistory in the southwest. Am Anthro 46:98-105

Heckenlively J, Friederich R, Farson C, Pabalis G (1981) Retinitis Pigmentosa in the Navajo. Metab Ped Opthmal 5:201-206

Hirsch DI (1954) Glottochronology and Eskimo and Eskimo-Aleut prehistory. Am Anthropol 66:825-839

Holve S, Hu D, Shub M, Tyson RW, Sokol RJ (1999) Liver disease in Navajo neuropathy. J Pediatr 135:482-493

Holve S, Hu D, McCandless SE (2001) Metachromatic leukodystrophy in the Navajo: fallout of the American-Indian Wars of the nineteenth century. Am J Med Genet 101:203-208

Holve S, Freidman B, Hoyme HE, Tarbby TJ, Johnstone S, Erickson RP, Clericuzio C, Cunniff C (2003) Athabascan brainstem dysgenesis syndrome. Am J Med Genet 120A:169-173

Jones GE, Ostergaard P, Moore AT, Connell FC, Williams D, Quarrell O, Brady AF, Spier I, Hazan F, Moldovan O, Wieczorek D, Mikat B et al (2014) Microcephaly with or without chorioretinopathy, lymphoedema, or mental retardation (MCLMR): review of phenotype associated with KIF11 mutations. Eur J Hum Genet 22: 881-887

Karadimas CL, Vu TH, Holve SA, Chronopoulou P, Quinzii C, Johnsen SD, Kurth J, Eggers E, Palenzuela L, Tanji K, Bonilla E, De Vivo DC, DiMauro S, Hitano M (2006) Navajo neurohepatopathy is caused by a mutation in the MPV17 gene. Am J Hum Genet 79: 544-548

Kaut CR (1956) Western apache clan and Phratry organization. Am Anthrol 58:140-146

Knowles BC, Roland JT, Krishnan M, Tyska MJ, Lapierre LA, Dickman PS, Goldenring JR, Shub MD (2014) Myosin Vb uncoupling from RAB8A and RAB11A elicits microvillus inclusion disease. J Clin Invest 124:2947-2962

Li L, Moshous D, Zhou Y, Wang J, Xie G, Salido E, Hu D, de Villartay J$\mathrm{P}$, Cowan MJ (2002a) A founder mutation in Artemis, an SNM1like protein, causes SCID in Athabaskan-speaking Native Americans. J Immunol 168:6323-6329

Li L, Zhou Y, Wang J, Hu D, Cowan MJ (2002b) Prenatal diagnosis and carrier detection for Athabaskan severe combined immunodeficiency disease. Prenatal Diag 22:763-768

Martinez-Caballos E, Gudas LJ (2008) Hoxa1 is required for the retinoic acid-induced differentiation of embryonic stem cells into neurons. $\mathrm{J}$ Neurosci Res 86:2809-2819

Moshous D, Pannetier C, de Chasseval R, le Deist F, Cavazzana-Calvo M, Romana S, Macintyre E, Canioni D, Brousse N, Fischer A, Casanova J-L, de Villartay J-P (2003) Partial T and B lymphocyte immunodeficiency and predisposition to lymphoma in patients with hypomorphic mutations in Artemis. J Clin Invest 111:381-387

Mroczek S, Krwawicz J, Kutner J, Lazniewski M, Kucinski I, Ginalski K, Dziembowski A (2012) C16orf57, a gene mutated in poikiloderma with neutropenia, encodes a putative phosphodiesterase responsible for the U6 snRNA 3-prime end modification. Genes Dev 26:19111925

Muller T, Hess MW, Schiefermeier N, Pfaller K, Ebner HL, Heinz-Erian P, Ponstingl H, Partsch J, Rollinghoff B, Kohler H, Berger T, Lenhartz $\mathrm{H}$ et al (2008) MYO5B mutations cause microvillus inclusion disease and disrupt epithelial cell polarity. Nat Genet 40:11631165

Nadja M, Capecchi M (2012) Cardiovascular defects in a mouse model of HOXA1 syndrome. Hum Mol Genet 21:26-31

Nicolas N, Moshous D, Cavazzana-Calvo M, Papadopoulo D, de Chasseval R, Le Deist F, Fischer A, de Villartay J-P (1998) A human severe combined immunodeficiency (SCID) condition with increased sensitivity to ionizing radiations and impaired V(D)J rearrangements defines a new DNA recombination/repair deficiency. J Exp Med 188:627-634

Opler ME (1936) The kinship systems of the Southern Athabaskan speaking tribes. Am Anthropol 38:620-633

Paster-Soler NM, Rafi MA, Hoffman JD, Hu D, Wenger DA (1994) Metachromatic dystrophy in the Navajo Indian population: a splice site mutation in intron 4 of the arylsulfatase gene. Hum Mutat 4: 199-207

Patterson NJ, Moorjani P, Luo Y, Mallick S, Rohland N, Zha Y, Genschoreck T, Reich D (2012) Ancient admixtures in human history. Genetics 192:1065-1093

Paulson HI, Garbern JY, Hoban TF, Krajewski KM, Lewis RA, Fischbeck KH, Gorrman RI, Lenkiski R, Kamholz JA, Me S (2002) Transient central nervous system white matter abnormalitiy in X-linked Charcot-Marie-Tooth disease. Ann Neurol 52:429-434

Raghavan M, Skoglund P, Graf KE, Metspaulu M, Albrechtsen A et al (2014) Upper Paeolithic Siberian genome reveals dual ancestry of Native Americans. Nature 505:87-91

Reich D, Patterson N, Campbell D, Tandon A et al (2012) Reconstructing Native American population history. Nature 488:370-374

Rual JE, Venkatesan K, Hao T, Hirozan-Kishikawa T, Dricot A, Li N, Berriz GF, Gibbons FD, Dreze M, Ayivi-Guedehoussou N et al 
(2005) Toward a proteome-scale map of the human protein-protein interaction network. Nature 437:1173-1178

Sapir E (1915) The Nadene languages: a preliminary report. Am Anthropol 17:534-538

Sikora M, Pitulko VV, Sousa VC, Allentoft ME, Vinner L et al (2019) The population history of northeastern Siberia since the Pleistocene. Nature:570182-570188

Singla V, Romaguera-Ros M, Garcia-Verdugo JM, Reiter JF (2010) $O f d 1$, a human disease gene, regulates the length and distal structure of centrioles. Dev Cell 18:420-424

Skeets J (2019) "Eyes bottle dark with a mouthful of flowers: poems by Jake Skeets". Milkweed Editions, Minneapolis, Minn., p. 24

Skoglund P, Mallick S, Bortolini MC, Chennagiri N, Hunemeier T, PetzlErler ML, Salzano FM, Patterson N, Reich D (2015) Genetic evidence for two founding populations of the Americas. Nature 525: 104-108

Spencer K (1947) Reflection of social life in the Navajo origin myth. Univ of New Mexico Publications in Anthropology No. 3

Spinazzola A, Massa V, Hirano M, Zeviana M (2008) Lack of founder effect for an identical mtDNA depletion syndrome (MDS)-associated MPV17 mutation shared by Navajos and Italians. Neuromuscul Disord 18:315-318

Tischfield MA, Bosley TM, Salih MAM, Alorainy IA, Sener EC, Nester MJ, Oystreck DT, Chan W-M, Andrews C, Erickson RP, Engle EC (2005) Homozygous HOXA1 mutations disrupt human brainstem, inner ear, cardiovascular and cognitive development. Nat Genet 37: 1035-1037

Tischfield MA, Erickson RP, Engle EC, (2016) HOXAl deficiency syndrome. In Erickson, R.P., And Wynshaw-Boris, A. (eds). Epstein's Inborn Errors of Development. The Molecular Basis of Clinical Disorders of Morphogenesis, 3rd edition, Oxford University Press

Toriello H (2009) Are the oral-facial-digital syndromes Ciliopathies? Am J Med Genet Part A 149A:1089-1095

Tvrdik P, Capecchi MR (2006) Reversal of Hoxl gene subfunctionalization in the mouse. Dev Cell 11:239-250

Viscomi C, Spinazzola A, Maggioni M, Fernandez-Vizarra E, Massa V, Pagano C, Vettor R, Mora ZM (2009) Early-onset liver mtDNA depletion and late-onset proteinuric nephropathy in Mpv17 knockout mice. Hum Mol Genet 18:12-26

Vogt EZ (1961) Chapter 5 in "Perspectives in American Indian Culture Change". In: Spicer EH (ed) Navajo. The University of Chicago Press, Chicago and London, pp 278-336
Volck B (2016) Attending others: a Doctor's education in bodies and words. Cascade Books, Eugene, p 179

Volk T, Pannicke U, Reisli I, Bulashevska A, Ritter J, Bjorkman A, Schaffer AA, Fliegauf M, Sayar EH, Salzer U, Fisch P, Pfeifer D et al (2015) DCLRE1C (ARTEMIS) mutations causing phenotypes ranging from atypical severe combined immunodeficiency to mere antibody deficiency. Hum Mol Genet 24:7361-7372

Volpi L, Roversi G, Colombo EA, Leijsten N, Concolino D, Calabria A, Mencarelli MA, Fimiani M, Macciardi F, Pfundt R, Schoenmakers EFPM, Larizza L (2010) Targeted next-generation sequencing appoints C16orf57 as Clericuzio-type poikiloderma with neutropenia gene. Am J Hum Genet 86:72-76

Vu TH, Tanji K, Holve SA, Bonilla E, Sokol RJ, Snyder RD, Fiore S, Deutsch GH, DiMauro S, De Vivo D (2001) Navajo neurohepatopathy: a mitochondrial DNA depletion syndrome? Hepatology 34:116-120

Wagner JK, Colwell C, Claw KG, Stone AC, Bolnick DA, Hawks J, Brothers KB, Garrison NA (2020) Fostering responsible research on ancient DNA. Am J Hum Genet 107:184-195

Wang LL, Gannavarapu A, Clericuzio CL, Erickson RP, Irvine AD, Plon SE (2003) Absence of RECQL4 mutations in poikiloderma with neutropenia in Navajo and non-Navajo patients. Am J Med Genet 118A:299-301

Wilson JAP (2005) Relatives halfway round the world: Southern Athabascans and Southern Tarim Fugitives. Limina 11:67-78

Wilson JAP (2011) Material culture correlates of the Athapaskan expansion: a cross-disciplinary approach, Ph.D. Dissertation. University of Florida

Xiao Z, Yannone SM, Dunn E, Cowan MJ (2009) A novel missense RAG-1 mutation results in T-B-NK+ SCID in Athabascanspeaking Dine Indians from the Canadian Northwest Territories. Eur J Hum Genet 17:205-212

Yi Z, Garrison N, Cohenn-Barak O, Karafet TM, King RA, Erickson RP, Hammer MF, Brilliant MH (2003) A 122.5 kilobase deletion of the $\mathrm{P}$ gene underlies the high prevalence of oculocutaneous albinism type 2 in the Navajo population. Am J Hum Genet 72:62-72

Publisher's note Springer Nature remains neutral with regard to jurisdictional claims in published maps and institutional affiliations. 